\title{
Gastric Pylorus Carcinoma
}

National Cancer Institute

\section{Source}

National Cancer Institute. Gastric Pylorus Carcinoma. NCI Thesaurus. Code C6795.

A carcinoma that arises from the pylorus. 